\title{
FISTULOUS RHEUMATISM A MANIFESTATION OF RHEUMATOID ARTHRITIS
}

BY

\author{
E. G. L. BYWATERS
}

From the Department of Medicine, Postgraduate Medical School of London, and the Special Unit for Juvenile Rheumatism, Canadian Red Cross Memorial Hospital, Taplow, Bucks

(RECEIVED FOR PUBLICATION APRIL 2, 1953)

The presence of fistulae discharging pus in the joints in granuloma inguinale (Donovan bodies? neighbourhood of a joint leads the physician to entertain the diagnosis of tuberculous infection, since this is the commonest chronic joint infection to break down in this way (e.g. Colvin, 1938; Steindler, 1938). Such fistulae are also seen in other types of long standing disease associated with tissue or bone necrosis, as in osteomyelitis, actinomycosis, or, elsewhere in the body, Krohn's disease. Cases have been recorded of such sinuses communicating with

Fig. 1.-Case 1, left foot and $x$ rays showing relationship of healed fistulae (marked by arrows) and underlying joint destruction.

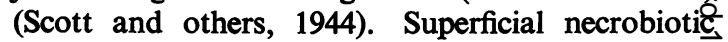
lesions not infrequently break down and discharge
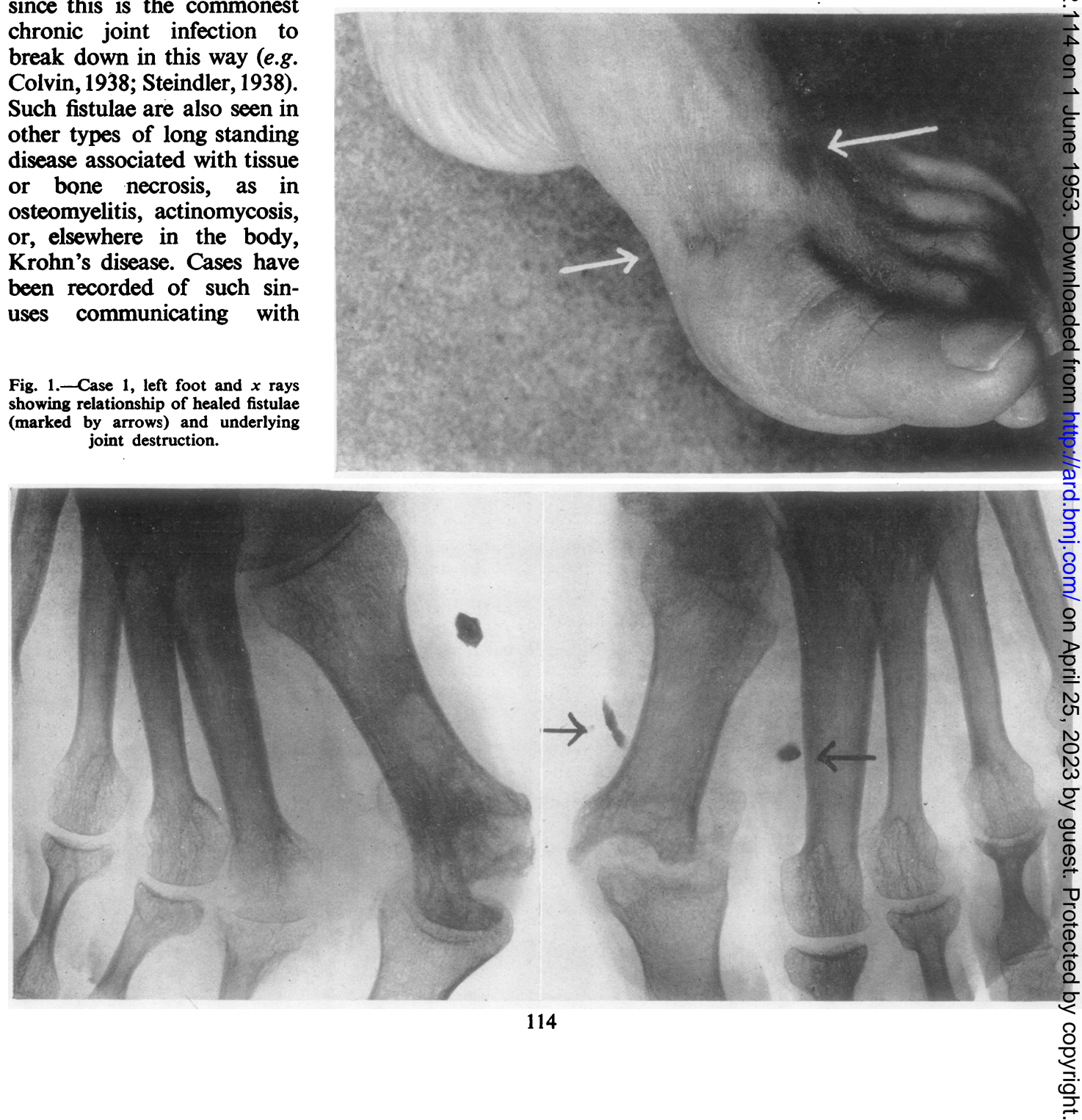
their necrotic contents; this is seen with subcutaneous urate deposits, calcific deposits, and occasionally with the ordinary subcutaneous nodules of rheumatoid arthritis.

In the two cases detailed below, discharging sinuses appeared in the neighbourhood of joints which were affected by chronic rheumatoid arthritis. This is thought worth recording in the apparent absence of its previous description.

\section{Case Reports}

Case 1.-Female, aged 57, was first seen at the Canadian Red Cross Memorial Hospital on July 6, 1948.

History.-Rheumatoid arthritis had started in the fingers in January, 1944, and spread thence to most of the limb joints. Gold produced no improvement. Since 1946, small indolent violaceous lumps had appeared near the base of the big toe and some of the finger joints. Each of these took about 2 months to come to a head, and then discharged a thick greyish yellow material on and off for a period of 1 to 2 years, until finally healing occurred. These lumps were still appearing. The only pathogen isolated was Staphylococcus pyogenes; cultures for blastomycosis and other organisms were negative.

Examination.-Typical rheumatoid arthritis affected many joints.

Erythrocyte sedimentation rate $40-50 \mathrm{~mm}$. $/ \mathrm{hr}$ (Westergren). Serum calcium, phosphorus, phosphatase, and uric acid normal.

Wassermann reaction negative.

Synovial fluid protein, $7 \cdot 8 \mathrm{~g}$. per cent., 18,500 cells per c.mm. with polymorphs 45 per cent., sugar $29 \mathrm{mg}$. per cent. (blood sugar, $58 \mathrm{mg}$. per cent.).

In relation to the joints showing most destruction radiologically (terminal interphalangeal left $V$ and right I, proximal interphalangeal right II and IV in the hands and in the feet, metatarsophalangeal I right and left), there were scars of healed or healing fistulae, usually two to each joint (Fig. 1); those on the left little finger and right thumb (Fig. 2) were discharging pus from swollen, but not painful, granulation tissue nodules. The $x$ ray showed cystic erosions and bone fragments lying in the soft tissue (Fig. 2). There was some swelling and slight reddening of the part. Biopsy of these two lesions showed no tuberculosis on culture. Histologically the area on the left little finger consisted of vascular

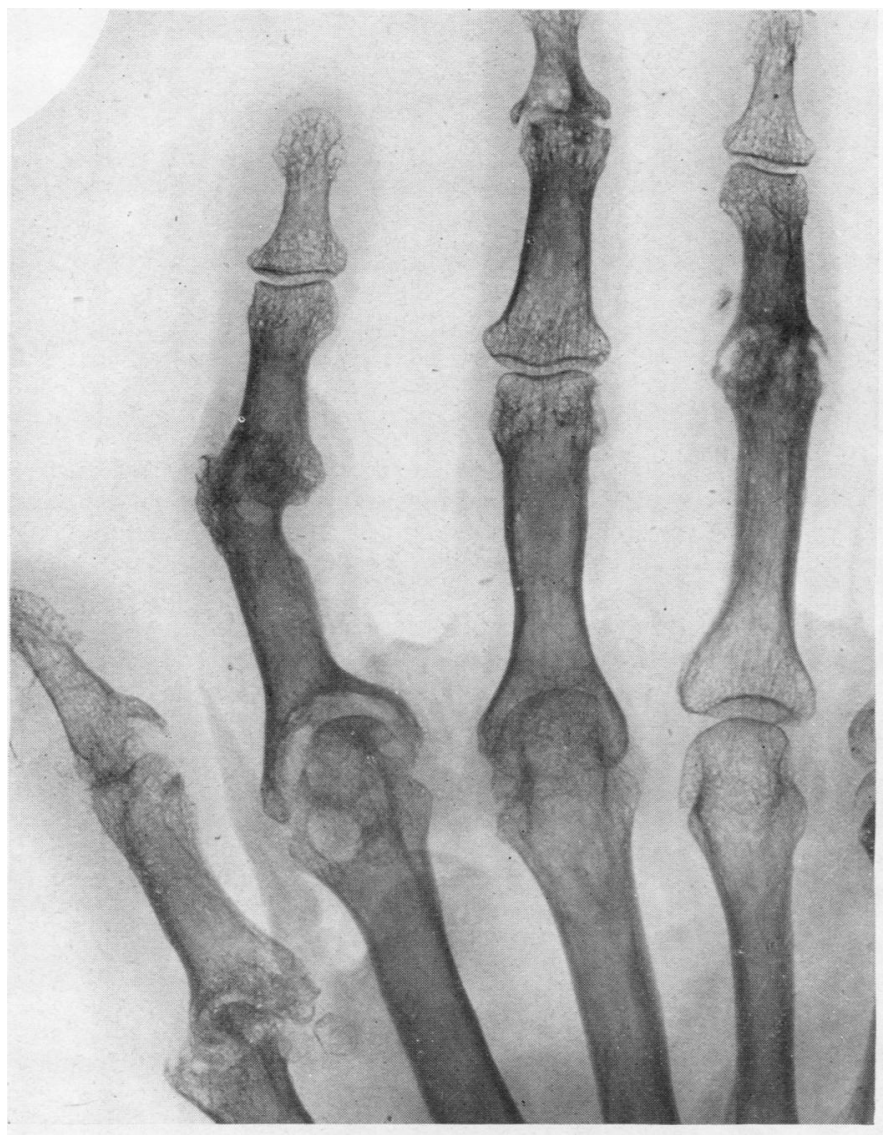

Fig. 2.-Case 1, right hand. Eight fistulae in relation to the four most severely affected joints. Note sequestra in soft tissues of ring finger and thumb.






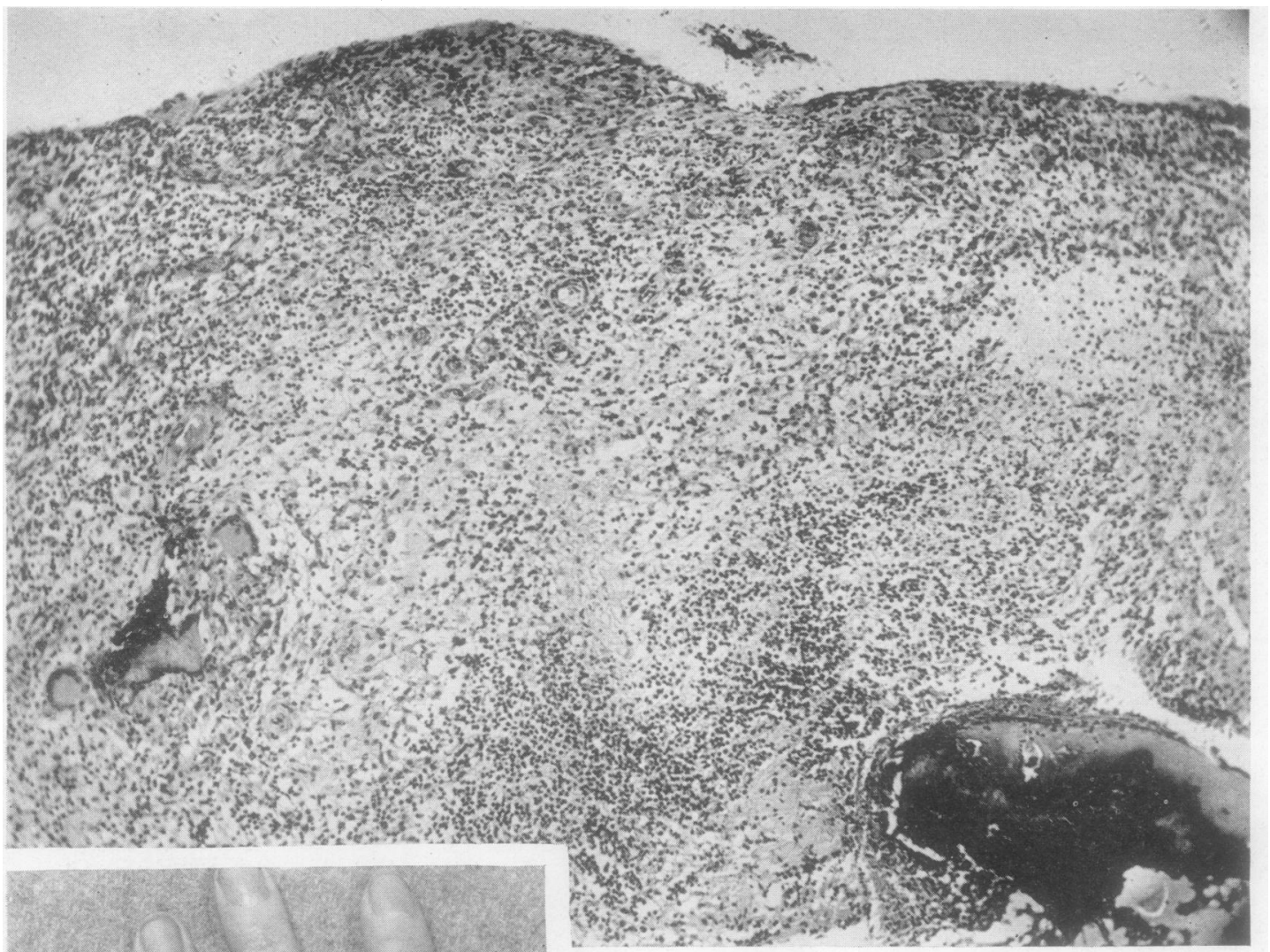

Fig. 3.-Case 1, granuloma (haematoxylin and eosin $\times 80$ ) from left fifth finger, showing necrotic bone and cartilage, giant cells, lymphocytes, etc.

History.-Rheumatoid arthritis had started in the left wrist in 1944, and spread to the feet and hands; erythrocyte sedimentation rate $35 \mathrm{~mm}$./ hr (Westergren).

In 1946, a nodular swelling over the left first metatarsophalangeal joint broke down and discharged. This discharge continued until January, 1947, when the joint was opened and drained.

In February, 1947, she was treated for focal sepsis in

granulation tissue, including polymorphs, lymphocytes, and splinters of bone and cartilage, surrounded by foreign-body giant cells (Fig. 3). The nodule on the thumb (Fig. 4), which was biopsied before it broke down, showed a similar granulomatous formation beneath the skin blister.

Follow-up.-In 1952, 4 years later, the patient's condition had changed but little. Similar nodules were still appearing in fresh places, but in relation to the same joints; breaking down, discharging and then gradually healing again.

Case 2.-Female, aged 41, was first seen at the Postgraduate Medical School of London on January 8, 1952. nother hospital.

In July, 1947, the nodules reappeared over the right and left big toe joints, broke down again, and discharged pus. In January, 1948, the head of the first left metatarsal bone was removed, together with all existing "nodules". However, 3 weeks after this operation, swelling and redness appeared over the right big toe; this eventually led to a fistula draining pus, which healed after 9 months. The right first metatarsophalangeal joint is now ankylosed.

Since that time, there have been four more flare-ups of these "nodules" in relation to the big toes; they followed the same pattern and showed little response to sulphonamide, chloromycetin, or penicillin, to which the patient 

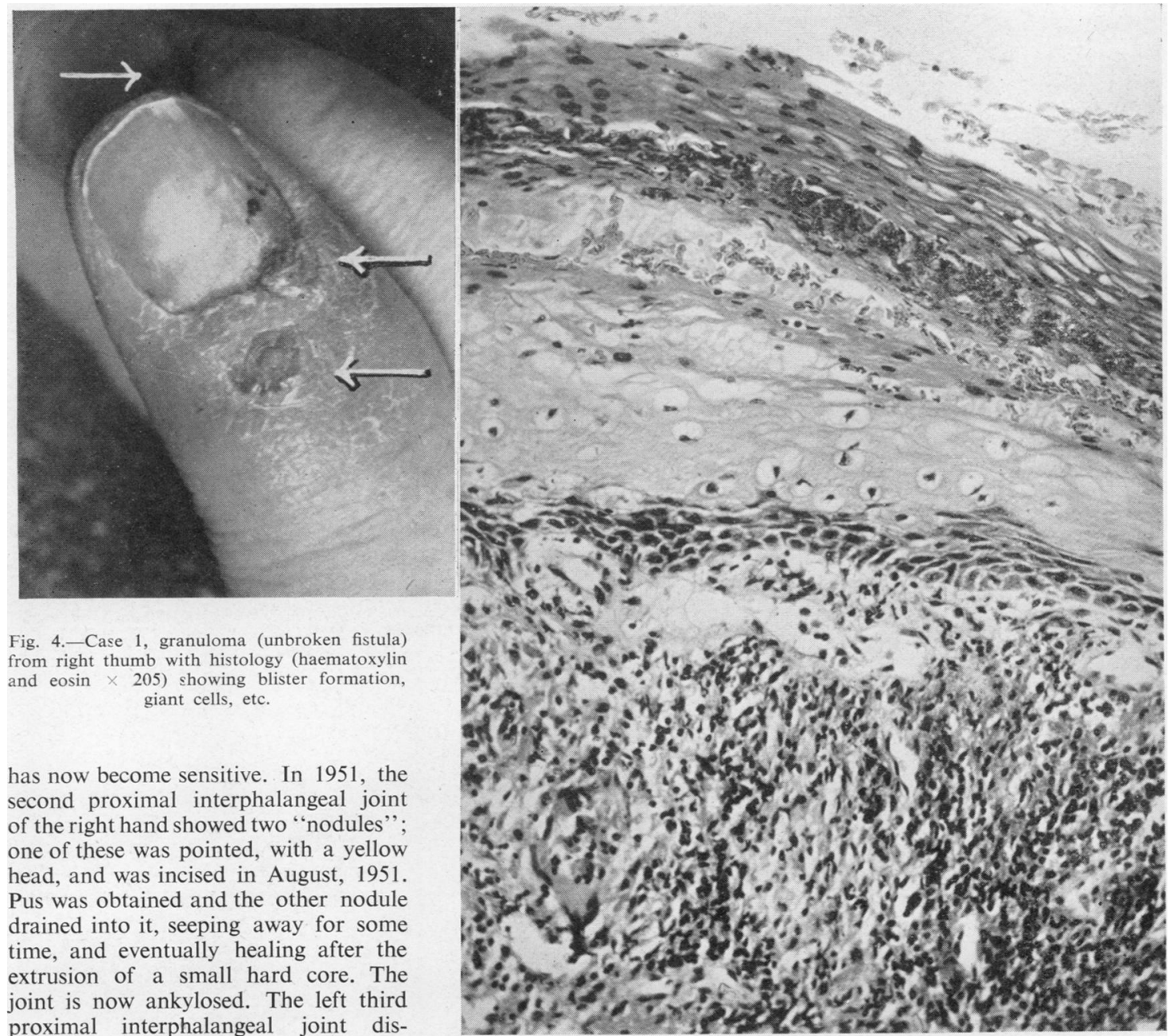

Fig. 4.-Case 1, granuloma (unbroken fistula) from right thumb with histology (haematoxylin and eosin $\times 205$ ) showing blister formation, giant cells, etc.

has now become sensitive. In 1951, the second proximal interphalangeal joint of the right hand showed two "nodules"; one of these was pointed, with a yellow head, and was incised in August, 1951. Pus was obtained and the other nodule drained into it, seeping away for some time, and eventually healing after the extrusion of a small hard core. The joint is now ankylosed. The left third proximal interphalangeal joint discharged a similar yellow watery fluid in August, 1952. The other joints during these 8 years have been the seat of intermittent acute episodes of rheumatoid activity, each leaving some residual deformity, despite which the patient continued cheerfully with her occupation (school nursing).

In July, 1952 (4 months before admission), an inflammatory swelling of the right palm appeared, which was thought to be a metastatic infection of the palmar bursa. This was opened at the wrist and drained pus intermittently.

Examination.-On admission to Hammersmith Hospital (in November, 1952), the patient showed classical rheumatoid arthritis with limitation of movement, deformity, soft tissue swelling, effusions of numerous joints, splenomegaly, and ordinary rheumatoid subcutaneous nodules (confirmed histologically) over the olecranon processes, on the Achilles tendon, the third left finger tendons, the palm and dorsum of left hand, and on the contact areas of the left fingers and thumbs.

Some joints were ankylosed, including one (left terminal big toe joint) not associated with cysts or fistulae.

There were discharging sinuses at the right wrist and on the dorsal aspect of the right big toe (proximal phalanx). In the neighbourhood of this joint, over the right and left first metatarsophalangeal joints, and over the right second proximal interphalangeaI joint, were seen the scars of healed fistulae (Fig. 5, overleaf).

Erythrocyte sedimentation rate varied between 24 and $52 \mathrm{~mm}$./hr; serum calcium $10 \cdot 2 \mathrm{mg}$. per cent., phosphate $2 \cdot 2 \mathrm{mg}$. per cent. (as phosphorus), alkaline phosphatase $25 \mathrm{KA}$ units, differential agglutination titre for sheep red cells $1: 64$; colloidal gold 5 units.

An $x$ ray taken in the out-patient department in January, 1952, showed large bone cysts in numerous joints. Those most severely affected were those in relation to which fistulae had occurred, or were shortly about to appear, i.e. the head of the right proximal big toe phalanx, the head of the third left proximal phalanx, and 


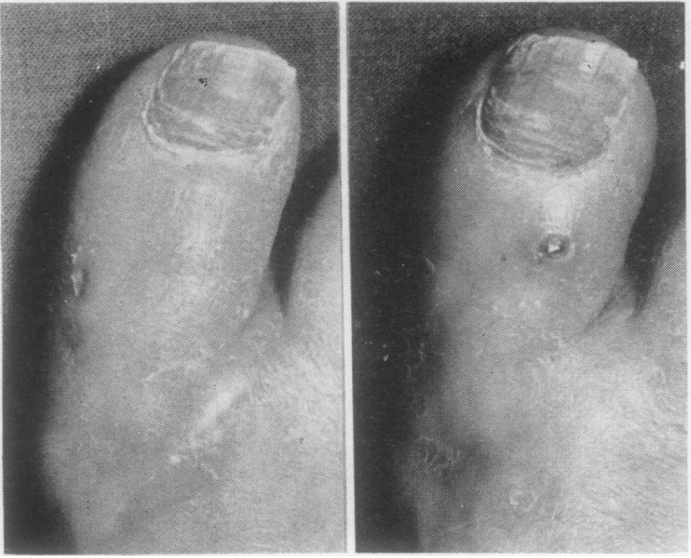

the head of the second right proximal phalanx. These we interpreted as herniations of synovial fluid and of rheumatoid granulation tissue into cancellous bone spaces exposed by erosion and attrition of cartilage. By November, 1952 (Fig. 5), the distal end of the right
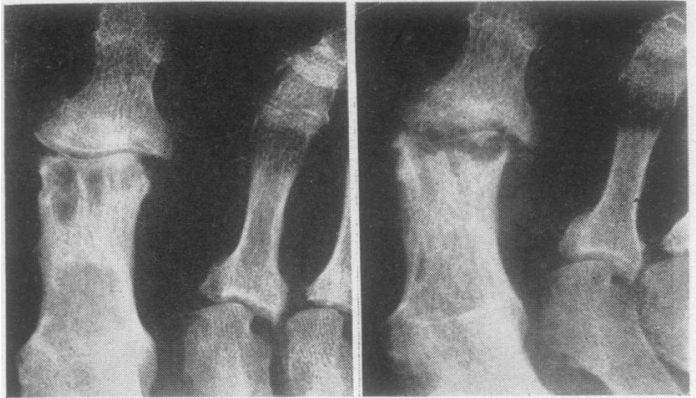

Fig. 5.-Case 2, new fistula forming in right big toe between January and October, 1952, in association with breakdown of bone cysts and $\rightarrow$ sequestrum formation.

proximal big toe phalanx had undergone destruction, 을 probably as a result of trauma to a structure weakened by the bone cysts. A sequestrum was visible in the joint $\check{c}$ cavity, and it is this, we suggest, which produced the $\frac{\overline{1}}{2}$ subsequent abscess.

Fig. 6(a).-Case 2. Joint surface $(\times 28)$ showing dense sclerotic bone with much new apposition, superficial pannus and fibrocartilage.

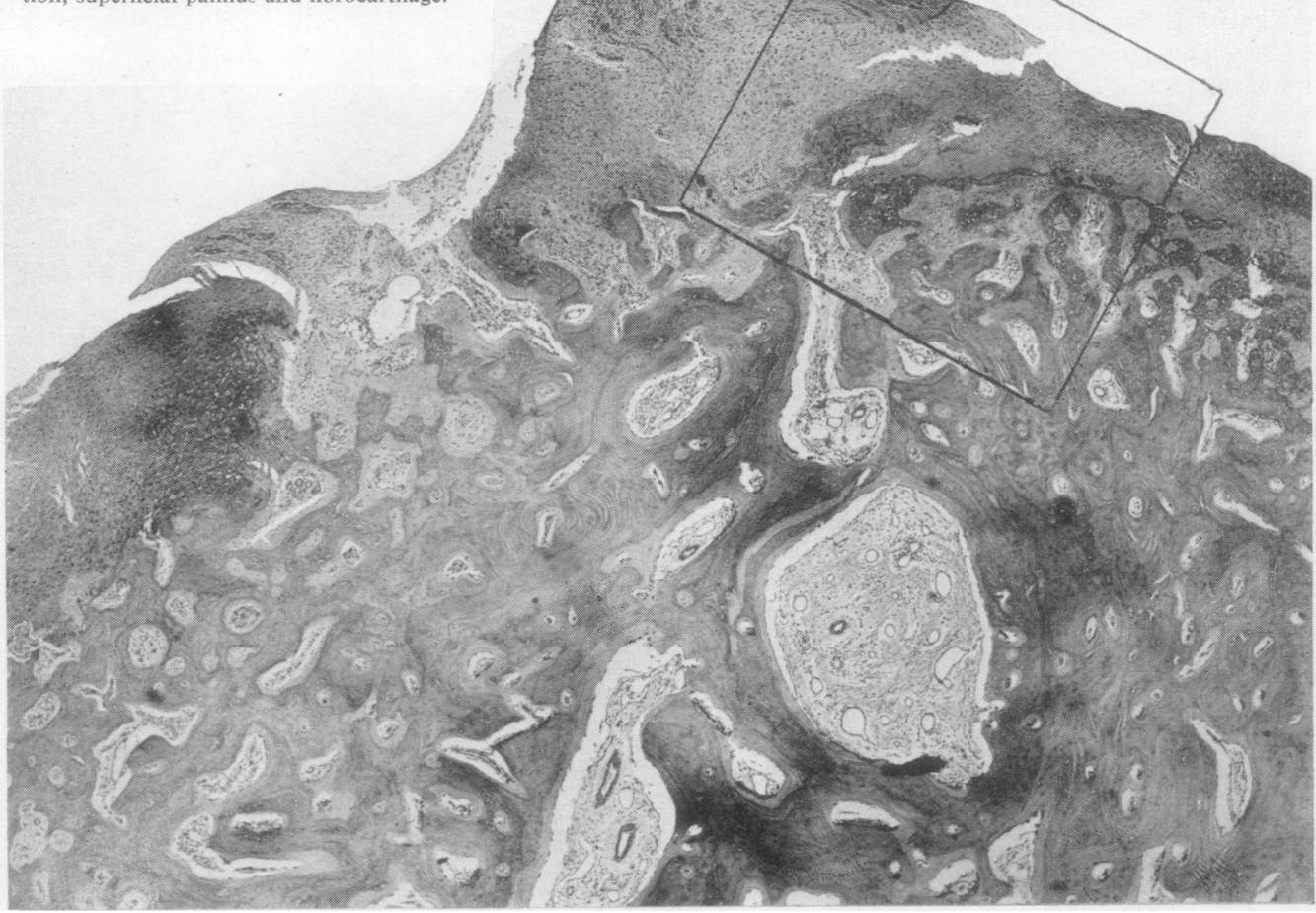




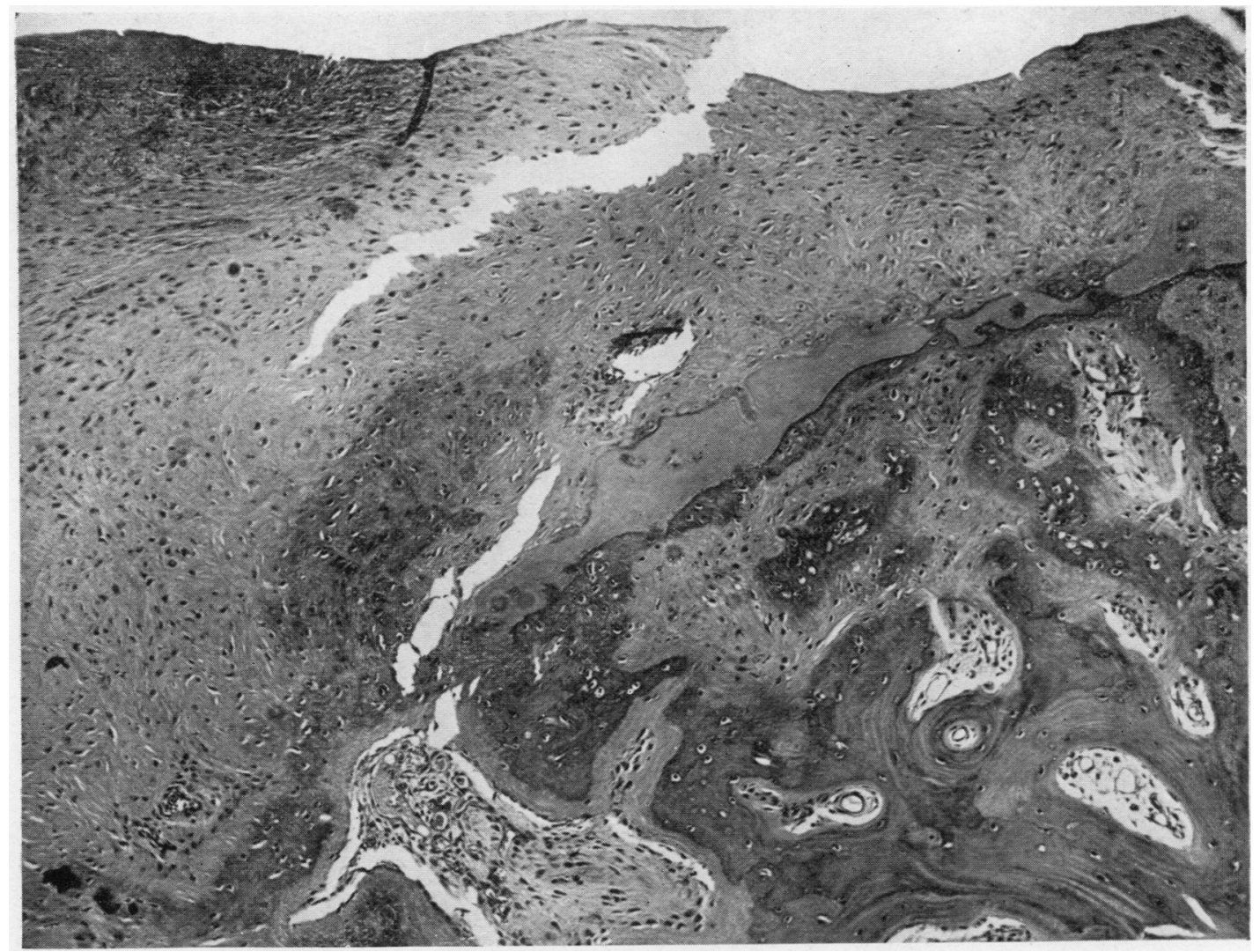

Fig. $6(b)$.-Case 2. Inset to $6(a)$ shows remains of hyaline cartilage, covered by pannus fibrocartilage, and underlain by woven bone $(\times 75)$.

In November, a culture from a healing fistula grew coagulase positive Staphylococcus pyogenes (penicillin resistant), but this was thought to be a superficial invasion, since another abscess, which appeared from the same joint, pointed a few weeks later (Fig. 5b), and was opened with sterile precautions, was found to be sterile on culture. Other cultures grew skin contaminants only. Investigations for tubercle bacilli, including culture and guinea-pig inoculation, were all negative.

In view of the inconvenience imposed by these fistulae, it was thought advisable to eradicate them surgically, and on December 1, 1952, after 2 days of penicillin injections, Mr. Stephenson removed the head of the proximal phalanx and the fistulous areas. No direct communication with the joint was found. The interior of the joint was full of soft vascular synovial processes typical of rheumatoid arthritis, but no naked sequestrum could be seen. Culture of the material removed grew Staphylococcus pyogenes. Histological examination (Figs $6 a$ and $b$, and $7 a$ and $b$, overleaf) showed that the bones taking part in the joint surface were extensively eroded. There was much new bone formation and sclerosis, side by side with areas of bone destruction by osteoclasts. The marrow spaces were in places invaded by granulation tissue containing large numbers of plasma cells and occasional lymphocytic foci: in places these intrusions formed large cysts, one of which contained a fragment of necrotic bone at its centre. Hyaline cartilage had almost disappeared (Fig. 6), and was covered by smooth surface pannus and fibro-cartil age. In places, new metaplastic fibro-cartilage formation was closing off the cancellous bone spaces, as is commonly seen in degenerative joint disease. Sections of synovial membrane (Fig. 7) showed a hyperplastic synovial membrane and a highly vascular connective tissue, containing small fragments of necrotic bone or cartilage, plasma cells, extravasated red blood cells, and aggregates of pyknotic nuclei, probably derived from polymorphonuclear leucocytes. There were a number of intact polymorphonuclear leucocytes in the superficial part of the membrane.

The picture was characteristic of that type of rheumatoid arthritis in which gross bone destruction has occurred: there was no evidence of any present pyogenic infection, nor were any organisms seen on Gram staining. 


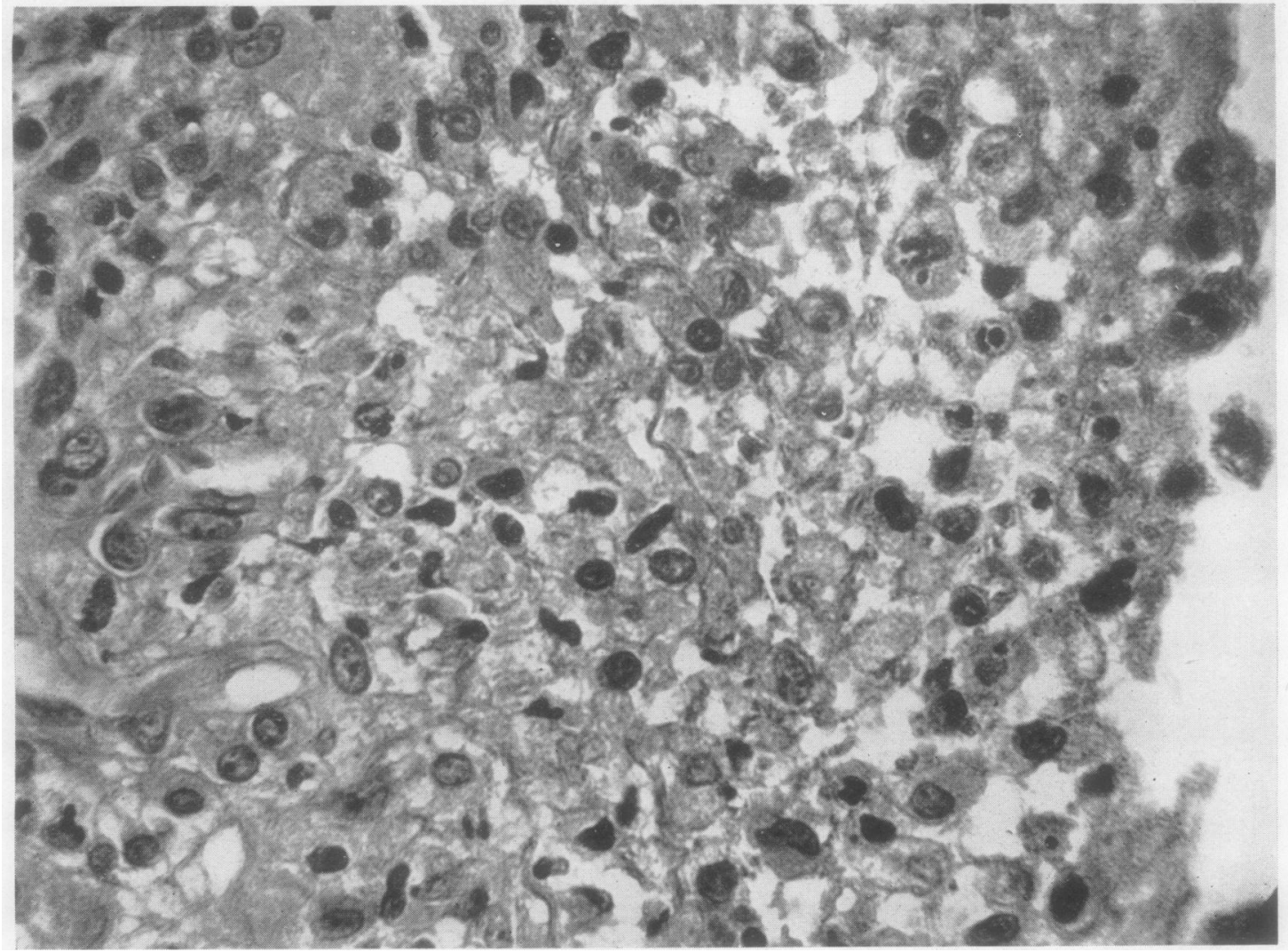

Fig. 7(a).-Case 2. Synovial membrane (haematoxylin and eosin $\times 700$ ) showing hyperplastic surface and rich capillary granulation tissue with a few polymorphs.

\section{Discussion}

Both these patients suffered from chronic rheumatoid polyarthritis starting in the synovial membrane and later producing bone and cartilage destruction.

What factor was responsible in these patients for this peculiar manifestation in certain joints? One possibility is secondary staphylococcal infection. We have seen patients with rheumatoid arthritis with superadded suppurative arthritis due to Staphylococcus pyogenes: the clinical picture is typical of an acute suppurative arthritis with intense pain, heat, swelling, redness, fever, and leucocytosis, quite unlike these indolent, mild, recidivous lesions. Although on occasion Staphylococcus pyogenes was cultured from each case, a more careful investigation of a pointing and unbroken abscess was sterile on culture. It seemed to us that the staphylococcus isolated was a secondary invader of the fistulous opening and was unable to spread back through the granulation tissue to involve the joint. Metastatic staphylococcal joint infection seemed to be a possible but improbable cause of the fistulae, firstly, because there were none of the clinical signs of staphylococcal joint infection, and, secondly, because there was no histological evidence of pyogenic joint infection.

The following seems to be a more probable sequence of events:

Rheumatoid destruction of cartilage leads to the formation of bone "cysts" by exposure of cancellous bone $\mathcal{N}$ spaces and the intrusion therein of synovial fluid under $N$ the pressure of movement, accompanied by rheumatoid 0 granulation tissue and occasionally by necrotic fragments $\omega$ of bone. These bone cysts enlarge, and, together perhaps with the daily trauma of use, lead to microfractures and 0 bone necrosis. Necrotic bone fragments are not uncom- $\overparen{D}$ monly seen histologically engulfed in the synovium of $\stackrel{\mathcal{D}}{?}$ banal rheumatoid arthritis surrounded by foreign body giant cells: they may occasionally be recognizable radio- $\overline{0}$ logically in uncomplicated rheumatoid arthritis, when $\underset{\mathbb{D}}{\vec{D}}$ they resemble the picture seen in Fig. 5. If numerous or $\stackrel{\rho}{\stackrel{\rho}{Q}}$

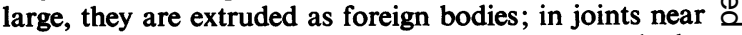
the surface, as here, these abscesses appear beneath the 


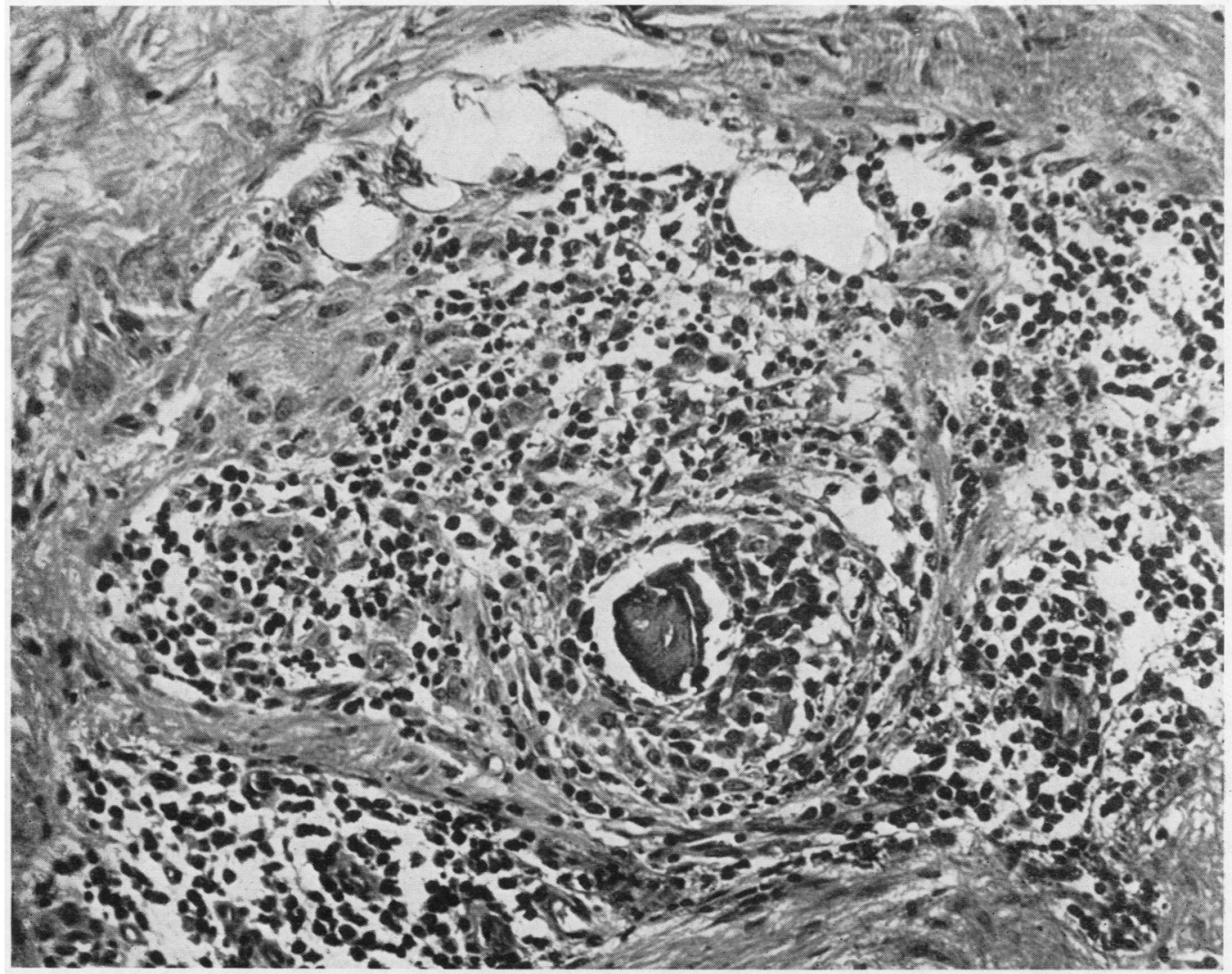

Fig. $7(b)$. - Necrotic bone fragment from middle of large bone cyst (haematoxylin and eosin $\times 210$ ).

skin and rupture. All these abscesses are in the neighbourhood of severely eroded and comparatively superficial joints: biopsy reveals cartilage and necrotic bone in the granulation tissue.

\section{Summary}

Two cases of rheumatoid arthritis are described in which bone destruction led to the appearance, on the surface of the skin in the neighbourhood of the affected joints, of abscesses and fistulae containing fragments of necrotic bone and cartilage.

I am much indebted to Dr. F. E. Smith, of Rugby, and Mr. L. H. F. Walton, of Camberley, who referred these cases and allowed me to use their notes, and to Dr. H. S. Barber, of Buxton, for additional information. Mr. P. J. Fiske took the photographs.

\section{REFERENCES}

Colvin, H. J. A. (1938), Proc, roy. Soc. Med. 31, 947. Scott, R. B., Lyford, J., and Johnson, R. W. (1944). Bull. Johns Hopk. Hosp., 74, 213.

Steindler, A. (1938). Sthwest. Med., 22, 168.

\section{Rhumatisme fistuleux. Manifestation de l'arthrite rhumatismale}

\section{RÉSUMÉ}

On décrit deux cas d'arthrite rhumatismale où la destruction osseuse mena à la formation au voisinage des articulations affectées d'abcès et de fistules cutanés contenant des fragments d'os et de cartilage nécrotique.

Reumatismo fistuloso. Manifestación de artritis reumatoide

\section{SUMARIO}

Se describe dos casos de artritis reumatoide en que la destrucción ósea motivó la formación en la vecindad de las articulaciones afectadas de abcesos y de fístulas cutáneas conteniendo fragmentos de hueso y de cartílago necróticos. 